\title{
The Impacts of Corporate Governance on Information Quality on Financial Statements
}

\author{
Huyen Pham Thu, Nga Nguyen Thi Hong, Nhung Dao Thi, \\ Hong Nguyen Thi Xuan, Nga Nguyen Thi \\ Hanoi University of Industry \\ Hanoi capital, Vietnam \\ phamthuhuyen@haui.edu.vn
}

\begin{abstract}
The core aim of this paper is studying corporate governance and information quality on financial statements, then summarize the results of last papers about the factors on the impacts of corporate governance on information quality on financial statements. Based on the content of these previous papers about this topic, this paper has identified the impact trend of each factor such as the characteristics of the board of directors (BOD), the audit committee (AC) on the quality of information on the financial statements. In addition, this paper also proposes further research involved in each factor. The content of this research expands the literature of the relevant research, and it is a useful reference for regulators and researchers.
\end{abstract}

Index Terms-corporate governance; the information quality on financial statements; financial statements.

\section{INTRODUCTION}

$\mathrm{I}$ $\mathrm{N}$ INTERNATIONAL integration of the economies, the competition in the market requires entities to ensure "healthy enough" to be able to maintain and develop the production of business. Moreover, the businesses must not only understand the entities by themselves but also obtain reasonable strategies and understand clearly legal policies and regulations if the enterprises are to develop stability. To do this, the entities must collect and present the information having good quality, high value. Information is one of the important factors to make success, increase value-added and enhance the competition ability of businesses in the market [1].

Financial statements are the outcome of the accounting department, presenting the financial information of the entittíe, and are considered as one of the most important sources for internal and external users such as administrators, investors, creditors... can analyze the financial capacity of the enterprise, thereby making decisions. Accounting information is a core sector in business management system, which managers always use in forceenable decisions and targets to effectively apply at work [2]. The quality of accounting information (QOAI)provided in the financial statements (FS) is a tool for CEO to control the economic - financial activities of enterprises. As a result, the entities obtain the challenges and opportunities from which to outline the strategies., management plan, business operation and these are the basis for making economic decisions. Furthermore, the accounting information also helps others such as authorities, investors, suppliers, creditors to have business plans, policy adjustments and obtain performance evaluations to achieve their purpose [3].
Research results of ACFE - Association of Fraud Investigators in the period 2016-2017 in 125 countries, there were 2,690 fraud cases that caused a loss of US\$7.1 billion, of which fraudulent financial statements despite accounts for only $10 \%$, less than property embezzlement, but causes a high average loss of $\$ 800,000$ per fraud. There were various errors in presenting accounting information which has caused negative impacts on the world economy, for example, because of fraud, embezzlement and excessive interference in the accounting work of managers with an amount of more than 600 million USD in the financial scandal of Tyco International group which operates in the field of pipeline construction in America [4]. Another instance, the intentional act of concealing the losses in Toshiba Corporation in Japan in the period from 2008 to 2014 by using tricks to overstate profits and overstate revenue up to $\$ 1.2$ billion. dollars... causing significant impacts on financial markets in the world [5].

There were numerous impacts on the reward of relevant in many ways if the managers used discretionary accounting methods and different techniques to prepare financial statements that positively describe business activities and financial position performance [6] or gain information on financial statements as they desired [7] to protect the reward of an individual or organisation [8]. There was a variety of papers about the influence on characteristics of corporate governance $(\mathrm{CG})$ on the QOAI presented, aspects studied such as: independence of BOD, BOD size, ownership characteristics, chief executive officer (CEO) earnings, characteristics of the audit committee. The main research direction of these studies is to examine the influence of factors related to the BOD, the Board of Supervisors or the AC on the quality of financial statement information. This paper studied repeatedly some independent variables such as: the independence of BOD, the AC, the CEO's duality, CEO's gender. In addition, each research paper contributes to the diversity of this topic of research by adding or changing the independent variable.

Based on summarizing and arranging papers followed by publication time, the paper will show the trends in the influence of elements on the quality of information on FS and propose further research related to this topic. For business owners, the paper provides evidence on the impact of CG on the quality of the information in the financial statements, then the business owners will take measures to control the activities of the BOD to limit the risk. Based on the over- 
view results, enterprises can issue regulations related to corporate governance to prevent information quality behavior on financial statements. Researchers can explore the research gap outlined in the paper to study future research on related topics.

The paper structure includes 4 main parts: Introduction, background theories, Methodology, Results and conclusion.

\section{BACKground Theories}

\section{A. Overview of corporate governance (CG)}

The origins of CG arise from the single of ownership from management in companies which is publiced on the stock market. This separation has measured the conflict between capital and operating capacity, between investors and managers, and this also created the risk of conflicts of reward, making the operating efficiency of the enterprise not reach the highest performance. CG is a system consisting of people, processes and activities that can help they have a management their assets [9]. Similar to this, there are studies that consider corporate governance as an important tool to control management activities in enterprises [10]. From the perspective of investors, research by Maines (2006) suggests that corporate governance is the commitment to pay a fair return on invested capital and ensure the efficient operation of business operations from investment capital [11]. From the above quotations, it can be seen that there are many different definitions of corporate governance, there is no concept of CG that can be used in every insitutiations and countries. However, most of the concepts put the enterprise at the centre position, so it can be summarized: CG is a system of relationships between stakeholders with interests. Sometimes conflicting interests related to the direction and control of the enterprise's activities to appropriately divide the rights and responsibilities.

\section{The Board of Directors (BOD)}

The BOD is a governance mechanism, consisting of members selected by shareholders, playing a central role in the supervisory system. With the assignment of the management department of the enterprise, the Board of Directors represents the shareholders to inspect and monitor the activities of the BOD, and plays a significant taskments in controlling the major issues [12].

In Vietnam, according to the Enterprise Law 2020 No. $59 / 2020$, the BOD is the management division of the company and has all authority on behalf of the company to decide and exercise the rights and obligations of the company, except rights and obligations under the authority of the General Meeting of Shareholders. Companies, depending on the characteristics of the business, will conduct the election of members of the BOD through the General Meeting of Shareholders, ensuring the provisions of the law on the structure of the BOD.

\section{Board of Supervisors (BOS)}

The BOS is a governance mechanism, consisting of surveyors elected by the General Meeting of Shareholders. Research by Bezemer et al (2012) suggests that the Board of Supervisors is the solution to the legal representative person. The supervision of the Supervisory Board minimizes the problem of asymmetry of information between shareholders and managers, preventing misleading acts for the personal purposes of executives [13]. In terms of management structure, not all joint- stock companies must have a Supervisory Board. This depends on the regulations of each country. In Vietnam, according to the Enterprise Law 2020 No. $59 / 2020$, joint-stock companies have the right to choose the management organization and operate according to one of two corporate governance models with or without a Supervisory Board but must have AC under the BOD. The organizational framwork, functions and duties of the $\mathrm{AC}$ are specified in the company's charter or the operation regulations of the AC issued by the BOD. Unlike the Supervisory Board, which supervises both the BOD and the BOD, the AC is a specialized department under the BOD, focusing mainly on the task of supervising the activities of the enterprise.

\section{B. The qualitative information of financial statements}

Financial statements are the outcome of financial accounting, the product of the accounting information system, reflecting in a strict structure the financial position and financial performance of the enterprise to meet the requirements of most people who used financial information in making economic decisions, it also shows the management results of the BOD with respect to the resources entrusted to these people (IASB, 2018). In order to adapt to changes in the international business environment following the trend of integration, financial statement information is understood in a wider and more multiway sense [8].On the other hand, the information provided by financial statements must be useful to users in any sense [14]. Overall, that the quality of information on FS is an emotional evaluation factor between the issuer of financial statements (mainly represented by organizations, enterprises, and companies) and those interested in enterprises (investors, policymakers, shareholders...) but can still be quantified to match the aspect of the information. While the smaller the difference between the required accounting information and the expected information in the FS, the higher the quality of information on the FS [15].

Various research, viewpoints of accounting professional organizations in different countries have agreed to describe the useful value of information on FS provided through the specific description of characters and requirements. The quality of information on FS are regulated by professional accounting organizations (IFRS Framework, FASB, AASB).

The International Accounting Standards Board (IASB) when issuing the International Accounting Standards (IAS/ IFRS) agreed that the common objective of FS is to "provide useful financial information to investors, lenders, other existing and potential creditors in decision-making". Therefore, in "Report on Accounting Concepts No. 8"- in chapter 3 (2010) when describing the qualitative characteristics of accounting information, it was supposed that "Accounting information is considered useful when it must be useful to what it implies and represents". As a result, when issuing the International Accounting Standards (IAS/IFRS), the common objective of financial statements is to "provide useful 
financial information to existing and potential stakeholders in decision-making". These aspects are shown in diagram 1:

Diagram 1: The QUalitative Characteristics OF FINANCIAL INFORMATION

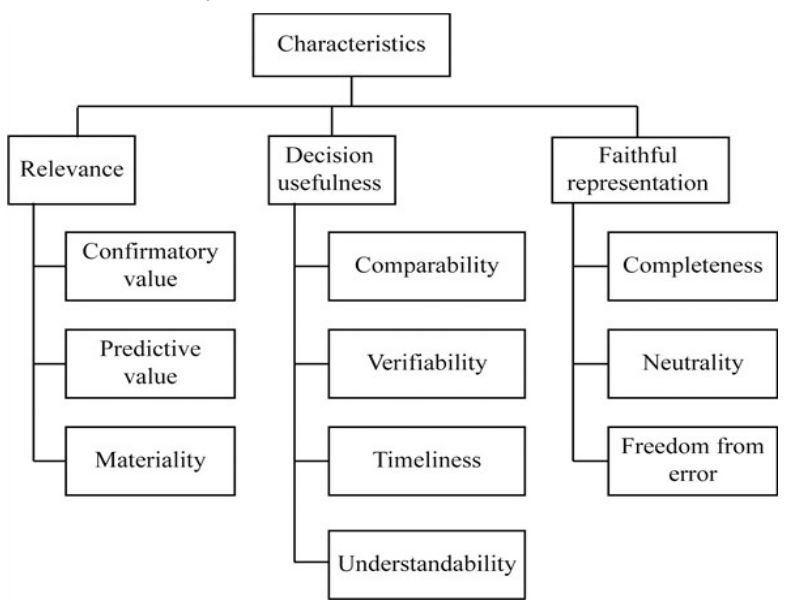

Source: According to IAS 01, 2010

\section{Methodology}

In this article, the authors have used qualitative research methods to synthesize research results on the influence of factors of corporate governance on the quality of information on FS from last papers on the world. Thereby, suggesting further research directions related to each factor. To find documents for the paper, we accessed many international databases such as: Emerald, ScienceDirect, Proquest, Google Scholar. The main keywords used to search are "corporate governance", "Fraud or Errors ", "financial reporting quality", "discretionary accruals". Criteria for selecting articles are based on the prestige of the journals in which the article is published.

To ensure that the previous research papers found which obtained high quality and relevant to the topic of financial reporting information quality, the papers are published in the journals listed with the keyword "Accounting". Initially, collect articles with a high number of citations, based on the reference list to continue to find related articles. After that, we continue to find out in magazines with one of the following keywords: "Finance", "Economics", "Business". Because the article is interested in the research involved in the impact on CG factors on the quality of financial statements information, from the articles found, we select the most relevant ones to the mentioned topic. and prioritize articles with the highest number of citations and the most recent publication time.

At first, we found 117 papers, after the selection steps described above, we kept 42 papers to use in this paper. Out of 42 previous papers, there was a paper published in 2002 , and one was published in 2009, these are two research articles with a high number of citations and published in prestigious journals, which play a leading role in the research related to the topic of this paper. The rest of the articles were published between 2012 and 2020.

\section{Results And Conclusion}

Corporate governance must ensure the disclosure of appropriate and truthful financial and non-financial informa- tion to shareholders. According to Maines (2016), in order to provide quality financial statement information, it is necessary to have an effective control mechanism for the preparation, presentation and disclosure of FS [11] The control function in corporate governance aims to monitor, supervise and check the process of preparing, presenting and disclosing information on financial statements [1]. Most of the previous studies when looking at the bond between $\mathrm{CG}$ and financial statement information quality were aimed at the $\mathrm{BOD}$ and the AC. The BOD and the AC as shareholder representatives supervise the Board of Management [6] and they are expected to monitor the quality of FS in order to increase the integrity of the FS. information on the FS. Cohen et al (2010) argue that CG factors such as: The BOD, the $\mathrm{AC}, .$. plays a noticeable sectorin ensuring the quality of FS information.

\section{A. The impact of BOD on the quality of financial information on FS}

Niu et al. (2006) argue that the characteristics of FS information strongly bank on the characteristics of CG [17]. In other words, the BOD is responsible for overseeing the company's financial reporting process [5].

\section{Size of BOD}

The size of BOD illustrates how many members of the BOD. With this character, the studies give different views, focusing on 3 directions: (a) BOD size has a positive relationship with the quality of financial statements [4]. (b) BOD size is negatively related to the quality of financial statements, for example: Panzer (2005) concludes that in companies with a smaller number of members of BOD, financial statements fraud rarely occurs. The third view (c) believes that the size of the BOD is not related to the quality of financial statements information [10].

\section{Duality}

The chairman of the BOD has control over the operations of the entity and has influence over the rank of management oversight and the FR process of the entity. One of the requirements of $\mathrm{CG}$ is to strengthen the supervisory function by limiting the concentration of power. The dual titles of General Director (CEO) and Chairman of the BOD often tend to concentrate power in one person. According to Alzoubi (2012), when managers have both incentives and opportunities, they will perform profit management behavior, which leads to low quality of financial report information. [20]. Anderson et al (2003) found that the separation of the roles of chief executive officer (CEO) and chairman of the BOD seems to have a positive impact on the (QOAI). [21]. Except for Cheng, Courtenay (2006), in their research did not find any correlation between duality and voluntary publication, most other studies concluded that the duality of two titles leads to deterioration of financial statement information quality [9]. Nadia Smaili, Réal Labelle (2009) believe that holding two positions will lead to fraudulent financial statements. [24].

Independent member of the Board of Directors (BOD)

Independent members of the BOD are members who are not responsible for running the company and are not dependent on the company, they are only involved in providing solutions and supervision for the CEO [5]. Forker (1992) ar- 
gues that the presence of non-executive members on the board of directors improves the quality of financial information $[12,23]$. These studies suggest that independent members of the BOD tend to protect the interests of shareholders more than others (Felo, 2003). According to Huang Zhizhong, Zhang Juan (2011) reviewed 880 republished reports of 465 listed companies on the Shanghai and Shenzhen Stock Exchanges of China, they argued that the proportion of independent members on the BOD with higher the level of governance, the less re-disclosure of financial statements [19]. And this feature also contributes to reducing financial reporting fraud (David B. Farber, 2004; Nadia Smaili, Réal Labelle, 2009) [4,7]. In contrast, different from the above studies, according to Srinivasan's (2004) study, there is a conclusion when providing evidence that independent members of the Board of Directors are involved in detected frauds related to financial information disclosed by the company.

\section{Member of the Board of Directors with expertise in financial accounting}

The BOD's financial accounting expertise is another element of board characteristics that may influence presenting financial statements. Directors with accounting expertise are skilled professionals, with experience working in the financial accounting field [20]. Professional members will help the Board of Directors in the orientation and strategy of monitoring the internal control system and risk management, controlling manipulation and ensuring the truthfulness of financial statement information. Empirical studies show that financial expertise is a decisive factor for the quality of financial statements $[4,15]$.

Despite there are still a few opposing views, most show that the presence of members with financial accounting expertise on the BOD, especially independent members of the BOD will contribute to enhancing the quality of financial statements information. Typically, there are studies by Agrawal \& Chadha (2004) that the presence of independent BOD with financial accounting expertise helps the BOD to better monitor the financial statement preparation process, thereby reducing the risk of financial fraud behavior of financial statements [6]. Meanwhile, Ismail et al. (2010) researched 400 listed companies in Malaysia, there was no evidence of any association between professional membership and the truthfulness of financial statement information [9].

\section{Frequency of meetings of the BOD}

The frequency of meetings of the BOD shows the number of meetings of the BOD in a given time unit, usually a year. The higher the meeting frequency, the more time the members of the BOD must discuss the issues of planning and monitoring the BOD. According to Xie et al. (2001), the BOD having many meetings has a positive relationship in reducing fraudulent behavior and increasing the quality of the information in FS.

\section{Board of Directors' gender}

Research by Barker and Mueller (2002) concluded that CEO gender has an impact on corporate governance policies. Accordingly, a series of studies check the influence of gender diversity on earnings management behavior. on the quality of information on the financial statements made. [13]. Most studies have found a negative relationship be- tween the presence of women on the BOD and the quality of information on FS, such as the study of Al Azeez et al (2019) claiming diverse Gender in the BOD will limit the behavior of profit management, thereby increasing the quality of the information in the FS [20]. Research by Lakhal et al (2015) gives different results that if there are more women in the BOD, the higher the quality of information on the FS and there should be at least three women on the BOD, this result is similar to Research by Arun et al (2015). However, the novelty of Arun et al. (2015) is to find a positive relationship between the number of female directors and the quality of information on financial statements in companies with high debt [15]. The negative relationship between the presence of women on the BOD and the quality of information on FS is again confirmed in the study of Gull et al (2018), Zalata, Tauringana, and Tingbani (2018) [22].

In conclusion, a general view of the studies examining the relationship between the characteristics of the board of directors and the quality of financial statements information has conflicting research results, so research in the future may continue to check this relationship to add to the reference.

Besides, in studies on the influence of governance characteristics on the quality of information on financial statements, researchers often exclude financial services and insurance companies in the survey sample. The researchers explain that the performance characteristics of these companies are different from the rest, which leads to the difference in financial information. This creates an opportunity for future research, this relationship can be explored in studies where the survey sample is companies dealing in financial services and insurance [16]. And with the trend of the market economy using later period data can provide more relevant results.

\section{B. The impact of the characteristics of supervisory board on the quality of information in the FS}

The Supervisory Board includes controllers elected by the General Meeting of Shareholders. Research by Bezemer et al (2007) suggests that the Supervisory Board is the solution to the agency problem. The Supervisory Board in the enterprise is obliged to supervise and evaluate the exercise of rights and obligations of the members of the BOD, the $\mathrm{Di}$ rector or the General Director of the company; monitoring and evaluating the effectiveness and compliance with internal audit regulations, risk management and prevention regulations, reporting regulations and other internal governance regulations of the company; supervise the legitimacy, systematicity and honesty in accounting work, accounting books, in the contents of financial statements. Accordingly, the Supervisory Board is expected to operate effectively, thereby improving the quality of financial statements [13]. Deriving from previous studies and collected data, the thesis studies the impact of the Supervisory Board's characteristics on the quality of the information in the FS in terms of size, seniority, expertise in finance and accounting and gender of the Supervisory Board member.

\section{The size of the Board of Supervisors}

The size of the Supervisory Board represents the number of members in the Supervisory Board. According to Firth et 
al. (2007), the size of the Supervisory Board is an important factor in improving the quality of financial statements because large-scale Supervisory Boards can have an advantage based on a broader knowledge base and therefore perform better. a more effective supervisory role. In addition, the increase in the number of members allows the members to divide the supervisory workload more appropriately, each member will have specific time and tasks to perform their responsibilities, so the financial statements With better quality, the information on the report becomes more relevant for users to make effective decisions [14]. This result is also agreed by Hendra (2016) [7]. However, some studies did not find evidence of the influence of Supervisory Board size on the quality of the information in financial statements such as Xie et al (2003) [4].

\section{Board of Supervisors' experience}

The seniority of the SupervisoryBoard represents the working time of the Supervisory Board members at the enterprise. Chen et al. (2006) argue that the attachment of the members of the Supervisory Board shows the experience and understanding of that member with the enterprise [10]. Sticking with the enterprise allows these members to gain working experience and at the same time understand the specifics of the business, especially the unit's internal control system, thereby improving supervision efficiency. , increasing the quality of information on financial statements. However, Anisykurlillah et al (2020) did not find evidence of the relationship between the seniority of the Supervisory Board and the quality of the information in the financial statements [15].

\section{Member of the Board of Supervisors with expertise in financial accounting}

Research by Anisykurlillah et al (2020) has shown a positive correlation between the financial expertise of the $\mathrm{Su}$ pervisory Board and the quality of the information in the financial statements [15]. The reason is that the knowledge of accounting and finance allows the members of the Supervisory Board to easily and independently access the accounting issues of the enterprise easily. They are qualified to evaluate the accounting methods, estimates and assumptions made on the company's financial statements in order to promptly detect and correct early years and residual errors on the financial statements. These members also have the ability to understand the issues of the independent auditor and assist the auditor in the event of a conflict with the Board of Directors to ensure the quality of the audit and the post-audit report. Ran et al (2015) also pointed out that when the Supervisory Board has expertise in the accounting field, they are able to detect profit management and financial fraud in a timely manner, thereby improving the quality of information. information on financial statements [23]. However, the study of Hendra (2016) did not find evidence of this relationship [18].

\section{The Board of Supervisors'gender}

When researching the quality of information on financial statements, many studies have demonstrated the positive impact of the presence of female members in the Supervisory Board on increasing the transparency of financial statements. Studies show that women are close supervisors in management, they value independence and are more likely to act in the interests of shareholders [19]. This is because they have more risk aversion and are more sensitive to ethical standards than men [11], so they have a higher level of vigilance to ensure confidentiality, and are suitable for supervisory roles. close $[9,23]$. In addition, women are also more likely to adhere to rules and regulations in making financial decisions than men [24]. From this, the authors believe that female members of the Supervisory Board will examine control activities more seriously and thoroughly than their male counterparts, so companies with a high percentage of female members on the Supervisory Board will promote the supervision function well, thereby improving the quality of the information in financial statements [23].

According to the research, the members of the Supervisory Board to ensure the good performance of the role of increasing the quality of the information in the financial statements need to meet the requirements such as having expertise in finance, accounting and being a woman. However, regulations on control boards in enterprises in different countries are different; Therefore, future research when studying the influence of the supervisory board on the quality of information on financial statements can be selected in emerging and developing economies and should pay attention to the specific regulations of each. nation. How is the identification of the role of the supervisory board before and after the application of corporate governance rules? Whether the quality of financial statements can be improved is still a topic that needs to be focused on research.

TABle 1. Some Studies ON THE INFLUENCE OF CORPORATE GOVERnANCE ON THE QUALITY OF THE INFORMATION IN FINANCIAL STATEMENTS

\begin{tabular}{|c|c|c|}
\hline Authors & Country & Results \\
\hline \multicolumn{3}{|c|}{$\begin{array}{l}\text { Studies on the influence of board characteristics on the quality } \\
\text { of information on financial statements }\end{array}$} \\
\hline Vafeas (2000) & America & $\begin{array}{l}\text { Board size has a adverse impact on the } \\
\text { quality of information on FS }\end{array}$ \\
\hline Xie et al (2003) & America & $\begin{array}{l}\text { The size of the BOD, the percentage } \\
\text { of independent members who are } \\
\text { organizations and the independent } \\
\text { members of the BOD with financial } \\
\text { expertise have a decisive impact on the } \\
\text { quality of information in the financial } \\
\text { statements. }\end{array}$ \\
\hline $\begin{array}{l}\text { Dimitropoulos } \\
\text { và Asteriou } \\
(2010)\end{array}$ & Greek & $\begin{array}{l}\text { The percentage of independent } \\
\text { members has a decisive impact on the } \\
\text { quality of information on FS. }\end{array}$ \\
\hline Fathi (2013) & France & $\begin{array}{l}\text { Board size, being audited by reputable } \\
\text { auditing firms have a decisive impact on } \\
\text { the quality of information in financial } \\
\text { statements. }\end{array}$ \\
\hline $\begin{array}{l}\text { Holtz và Sarlo } \\
\text { Neto (2014) }\end{array}$ & Brazil & $\begin{array}{l}\text { The number of members of the BOD } \\
\text { and the duality of the chairman of the } \\
\text { Board of Directors have an adverse } \\
\text { impact on the quality of information in } \\
\text { the FS. } \\
\text { The percentage of independent } \\
\text { members has a decisive impact on the } \\
\text { quality of information on FS. }\end{array}$ \\
\hline $\begin{array}{l}\text { Kukah và cộng } \\
\text { sự (2016) }\end{array}$ & Ghana & $\begin{array}{l}\text { The independence of the BOD, the } \\
\text { non-duality between the two titles of } \\
\text { Chairman of the BOD and CEO has a } \\
\text { positive impact on the quality of } \\
\text { information in the FS. }\end{array}$ \\
\hline
\end{tabular}




\begin{tabular}{|c|l|l|}
\hline Authors & Country & Results \\
\hline $\begin{array}{c}\text { Roden at el } \\
\text { (2016) }\end{array}$ & America & $\begin{array}{l}\text { The seniority of the Board of } \\
\text { Directors, the duality between the two } \\
\text { titles of Chairman of the Board of } \\
\text { Directors and CEO, the proportion of } \\
\text { members of the Board of Directors who } \\
\text { are male have a negative impact on the } \\
\text { (QOAI). }\end{array}$ \\
\hline \begin{tabular}{|c|l|} 
Studies on the influence of Supervisory Board characteristics on \\
the quality of information on financial statements
\end{tabular} \\
\hline $\begin{array}{c}\text { Firth et al } \\
\text { (2007) }\end{array}$ & China & $\begin{array}{l}\text { The size of the Supervisory Board has } \\
\text { a decisive impact on the quality of } \\
\text { information in the FS. }\end{array}$ \\
\hline Ran et al (2014) & China & $\begin{array}{l}\text { Members of the Supervisory Board } \\
\text { have accounting expertise and the } \\
\text { Supervisory Board has a high } \\
\text { percentage of women, which has a } \\
\text { decisive impact on the quality of } \\
\text { information in the FS. }\end{array}$ \\
\hline $\begin{array}{c}\text { Panzer và } \\
\text { Müller (2015) }\end{array}$ & Germany & $\begin{array}{l}\text { The members of the Supervisory } \\
\text { Board and the deputy head of the } \\
\text { Supervisory Board are women with an } \\
\text { decisive impact on the quality of } \\
\text { information on FS }\end{array}$ \\
\hline
\end{tabular}

Source: Synthetic group of authors

\section{Conclusion}

The paper summarizes the previous research results on corporate governance to the quality of information on financial statements, in which, the factors of corporate governance are considered: the size of the board of directors, gender in the BOD, CEO duality, audit committee characteristics... This topic can be explored for future research by expanding the object of analysis, paying attention to specific businesses such as financial companies, insurance and should choose the research context as countries with developing economies. In addition, the in-depth research on the elements of corporate governance also creates opportunities for further research, for example when studying the influence of CEO duality on the quality of information on FS combined with the CEO tenure.

One of the limitations of the paper is that the number of research articles is not much, so it is possible to omit other elements of the corporate governance mechanism. Secondly, although mentioned, not deeply analyzed the control variables in the research model of the authors. Thirdly, the paper only stops at an overview, identifies the impact trend, but has not tested the specific model. Despite the mentioned limitations, the results of the article have increased the content of the literature review on the topic of information quality on FS, so researchers may be interested in research proposals. In another aspect, this will be a remarkable reference when authorities issue regulations on corporate governance mechanisms, aiming to limit the quality of information on FS, ensuring the quality of the FS.

\section{REFERENCES}

[1] Liu \& Lu, Corporate governance and earnings management in the Chinese listed companies: A tunneling perspective, Journal of Corporate Finance, Vol.13, 2007, pp.881-906

[2] Huang, K. T., Lee, Y. W., Wang, R. Y. Quality information and Knowledge, New Jersey: Prentice Hall, 2007, pp.281-311

[3] Gacheru, F.A.I.T.H. Effect of Financial Accounting Information Quality on Decision Making: a Survey of Public Benefit Organizations in Nairobi County, 2017, pp.811-825

[4] Xia, B. and Zhao, C., January. Empirical Research of the Relationship between Characteristics of Supervisory Board and Earnings Quality. In 2009 Second International Workshop on Knowledge Discovery and Data Mining, 2009, pp. 409-412.

[5] Roden, D.M., Cox, S.R. and Kim, J.Y. The fraud triangle as a predictor of corporate fraud. Academy of Accounting and Financial Studies Journal, 2016, 20(1), p.80.

[6] Hendra, G.I. Analysis of the Effect of Sharia Supervisory Board (SSB) Function on Earning Quality of Islamic Banks. Tazkia Islamic Finance and Business Review, 2016, 10(2).

[7] Well, Joseph T., Corporate fraud handbook: Prevention and Detection, Wiley, Hoboken, ISBN 9781118757260, 2013.

[8] Azar, N., Zakaria, Z. and Sulaiman, N.A. The Quality of Accounting Information: Relevance or Value- Relevance?.Asian Journal of Accounting Perspectives, 2019, 12(1), pp.1-21.

[9] Mulyani, S. and Arum, E.D.P. The influence of manager competency and internal control effectiveness toward accounting information quality. International Journal of Applied Business and Economic Research, 2016, 14(1), pp.181-190.

[10] Chen, H., Chen, J. Z., Lobo, G. J., \& Wang, Y. Effects of audit quality on earnings management and cost of equity capital: Evidence from China. Contemporary Accounting Research, 2011, 28(3), 892-925.

[11] Maines, L.A. and Wahlen, J.M. The nature of accounting information reliability: Inferences from archival and experimental research. Accounting Horizons, 2006, 20(4), pp.399-425.

[12] García-Meca, E. and Sánchez-Ballesta, J.P. Corporate governance and earnings management: A meta-analysis. Corporate governance: an international review, 2009, 17(5), pp.594-610.

[13] Bezemer, P. J., Peij, S .C., Maassen, G. F. and van Halder, H. The changing role of the supervisory board chairman: the case of the Netherlands (1997- 2007). Journal of Management \& Governance, 2012, 16(1), pp.37-55.

[14] Healy, P.M. and Wahlen, J. M. A review of the earnings management literature and its implications for standard setting. Accounting horizons, 1999, 13(4), pp.365-383.

[15] Kahn, Beverly K., and Diane M. Strong. Product and Service Performance Model for Information Quality: An Update. IQ, 1998, 102-115.

[16] Cohen, D., and P. Zarowin. Accrual-based and real earnings management activities around seasoned equity offerings. Journal of Accounting \& Economics 50 (1): 2-19 companies: A tunneling perspective, Journal of Corporate Finance, 2016, Vol.13, pp.881-906,

[17] Niu, F. F., Corporate governance and the quality of accounting earnings: a Canadian perspective. International Journal of Managerial Finance, 2006, 2(4), 302- 327.

[18] Panzer, L. and Müller, S. Earnings quality and gender diversity on German supervisory boards: an empirical analysis. Problems and perspectives in management, 2015, (13, Iss. 4), pp.9-18.

[19] Panzer, L. and Müller, S. Earnings quality and gender diversity on German supervisory boards: an empirical analysis. Problems and perspectives in management, 2015, (13, Iss. 4), pp.9-18.

[20] Alchian, A.A. and Demsetz, H. Production, information costs, and economic organization. The American economic review, 1972, 62(5), pp.777-795.

[21] Afify, H.A.E. Determinants of audit report lag. Journal of Applied Accounting Research, 2009, Vol. 10 No. 1, pp. 56-86.

[22] Vafeas, N. Board structure and the informativeness of earnings. Journal of Accounting and Public policy, 2000, 19(2), pp.139-160.

[23] Ran, G., Fang, Q., Luo, S. and Chan, K.C. Supervisory board characteristics and accounting information quality: Evidence from China. International Review of Economics \& Finance, 2015, 37, pp.18-32.

[24] Bernardi, R.A. and Arnold Sr, D.F. An examination of moral development within public accounting by gender, staff level, and firm. Contemporary Accounting Research, 1997, 14(4), pp.653668 . 